\title{
IMPACTS OF THE EU STRATEGY FOR THE DANUBE REGION (EUSDR) IN LIGHT OF TRANSPORT VOLUMES ON THE DANUBE RIVER
}

\author{
Dávid NAGY ${ }^{\mathrm{a}}$, András MUNKÁCSY ${ }^{\mathrm{b}}$, Melinda JÁSZBERÉNYI ${ }^{\mathrm{c}}$ \\ ${ }^{a}$ PhD student, University of Pécs, Doctoral Programme in Earth Sciences, david@info-partner.hu \\ ${ }^{\mathrm{b}}$ Researcher, KTI Institute for Transport Sciences, munkacsy.andras@kti.hu \\ c Lecturer, Corvinus University of Budapest, jaszberenyi@uni-corvinus.hu
}

Cite this article: Nagy, D., Munkácsy, A., Jászberényi, M. (2019). Impacts of the EU Strategy for the Danube Region (EUSDR) in light of transport volumes on the Danube river. Deturope. 11(3), 59-79.

\begin{abstract}
Although the EU Strategy for the Danube Region (EUSDR) is a macro-regional policy document of the European Union, it pays special attention to the development of the Danube, the river it is named after. In the field of transport, an EUSDR priority area (1a) is dedicated especially to waterways mobility, addressing mainly transportation on the Danube. One of the key targets is to increase cargo transport on the river by $20 \%$ by 2020 in relation to the base year of 2010 . In recent years, there is growing interest in analyzing the implementation of EUSDR, but inland navigation related results are still under-researched. This paper aims to fill this gap by a late mid-term evaluation of EUSDR's impact in inland waterway transport on the Danube. Therefore, projects in line with EUSDR are reviewed in order to understand the commitment and efforts of countries. On this basis, data on freight transport volumes are compared. The analysis focuses not only on single countries but also on three (Upper, Middle, and Lower) sections of the river to reveal regional characteristics and differences. Findings indicate that the expected increase of transport volumes on the Danube is not being achieved, as transport volumes declined from 2010 to 2017.
\end{abstract}

Keywords: EUSDR, Danube, inland waterway transport

\section{INTRODUCTION}

For a long time, utilization of the Danube River as a waterway lagged behind opportunities. The main reason was political fragmentation, since the river passed through borders of cultures and empires. There was no chance for the establishment of a single economic area in its catchment basin when Danube riparian countries started to develop, transportation needs quickly increased, and the largest competitor, namely railways, appeared in the $19^{\text {th }}$ century. As a result of efficient waterway development and transportation needs of heavy industry emerged by Soviet imperial interests along the Danube, inland waterway transport (IWT) burgeoned in the second part of the $20^{\text {th }}$ century (Hardi 2012). 
Waterway infrastructure and maintenance are crucial for inland navigation. Both require large financial resources; furthermore, financing of management and maintenance (of both waterway infrastructure and ports) are often separated, thus coordination is a key issue (Beyer 2018). The international character of the Danube makes waterway management even more complicated, which requires cooperation of all the riparian states. Some other factors, such as climate change, economic constraints and policy also have a large influence on the IWT sector.

The European Union is promoting the development and expansion of the IWT (and rail) sector to increase its modal share and subsequently reduce air and noise pollution and optimise land use by road transport. The EU Strategy for the Danube Region (EUSDR) defined the target of increasing cargo transport on the Danube River by $20 \%$ by 2020 in relation to the base year of 2010. Further aim of EUSDR was to increase physical capacity of the Danube by removing bottlenecks to accommodate pushed convoys and vessels with a draught of up to 2.5 meters (VIb type vessels according to UNECE's international classification) all year round by 2015 (subsequently rescheduled for 2020). To achieve these aims, infrastructure development of the waterway and ports, as well as modernisation of navigation and IT systems were foreseen.

The macro-regional strategy has been implemented; developments of different scales have been concluded or are still ongoing on both national and transnational level. By the analysis of statistical data on country and regional level along the Danube, this paper addresses the impacts of EU co-funded and national projects on IWT. Some research questions are as follows:

- Are there national or regional (i. e. country or river section related) characteristics in terms of investment volumes and project objectives in line with priority area 1a (Waterways Mobility) of EUSDR?

- Are there clear differences among groups of countries of the three sections (geographical regions) of the Danube in terms of IWT indicators?

- Are EUSDR's ambitious aims achievable and which are the key barriers?

- Are targets of EUSDR being achieved along the entire river and in each of its three sections?

To set the scene, first a literature review is provided, and then methodology is described. EUSDR projects are studied in general and by two key issues (bottlenecks and transport volumes) in the Results section. Finally, the findings are highlighted. 
Nagy, D., Munkácsy, A., Jászberényi, M.

\section{THEORETICAL BACKGROUND AND LITERATURE REVIEW}

There are relevant differences in the Danube Region in terms of socioeconomic status. Indicators of Germany and Austria (Upper section) are significantly better (Müller \& Hannes 2015, Erdősi et al 2013): GDP related indicators clearly show better perfomances in these countries. Among others, foreign direct investment as a percentage of GDP is much higher in EU member states of the Middle (Slovakia, Hungary, Croatia, and Serbia; EU member states in italics), and Lower section (Bulgaria and Romania).

Priority area 1 of EUSDR intends to develop road, rail, air, and inland waterway transport in order "To Improve Mobility and Multimodality". Although the macro-region has quite good accessibility indicators, the average value of 68 of the Logistics Performance Index (LPI) justifies the need for action (Rafaelsen et al. 2017). There are relatively large differences among countries; LPIs in the Upper (138-150), Middle (81-86), and Lower section (51-60) illustrate diversity. In the Lower section, especially in Romania, the lack of high level road infrastructure increases the importance of inland navigation and the role of intermodal links (Ţarţavulea, Belu, \& Paraschiv, 2011).

According to the EU Transport Scoreboard, the TEN-T inland waterways' core network was completed in nearly all member states by the end of 2016, when only Croatia (33\%) and Romania (91\%) had incomplete elements. (In the case of Croatia, other waterways, especially the Sava and Drava rivers also relevantly count here.) However, a detailed study of the IWT sector-such as navigable days, competitiveness, and performances of cargo transport- would show quite a different (and less positive) picture. Connected waterways and multimodal links of the TEN-T network are subjects to further development as well.

By review of the literature, it may be concluded that impacts of the EU Strategy for the Danube Region have not yet been extensively studied. Besides some indirectly related sectoral analyses (e. g. Ignjatijević, Milojević, Cvijanović, \& Jandrić, 2015), only a few reports or articles focus on general outcomes. A study by Bettina and Hannes (2015) addresses future potentials, needs, and socioeconomic challenges of the Danube Region. A discussion paper by Chilla and Sielker (2016) raise questions about monitoring, evaluation and added value of EUSDR. Sielker (2016) aims to understand new drivers of cooperation and multi-level governance by EUSDR stakeholders' perspectives. Ngampramuan (2018) studies EUSDR's contribution on regional and sub-regional, as well as further territorial (local, provincial, 
Nagy, D., Munkácsy, A., Jászberényi, M.

national) levels. A discussion paper by Gál, Lux, and Illés (2013) provides a comprehensive analysis of the Danube Region and structured information to understand territorial specificities. Regional differences, comparing countries of the three (Upper, Middle, and Lower/Under) sections of the Danube River at the moment of implementation of EUSDR are illustrated by the findings in terms of unemployment rates, higher education degrees, and research and innovation spending per capita, by Czakó, Fekete, and Poreisz (2014).

As most European countries have no interest in the IWT industry at all, inland navigation is an under-researched field of transport. Thus, the number of recent articles about shipping even on the Danube is low, focusing mainly on river engineering and the burning issue of navigability (e. g. Beuthe et al. 2014, Habersack et al. 2016, Glock et al. 2019). However, there are some scientific publications which address current navigation challenges and potentials in the Danube macro-region. For instance, two articles consider the steps to be taken for the promotion of IWT at the moment of implementation of EUSDR: 1) Mihic, Golusin, and Mihajlovic (2011) present measures to stimulate sustainable development in the Danube Region on the basis of previous research findings and regulatory documents; and 2) Radmilović and Maraš (2011) map the advantages and disadvantages of inland navigation to provide a general overview of the (sub)sector and its future in the Danube Region. A recent study by Pfoser, Jung, and Putz (2018) reviews administrative barriers delimitating economic and environmental potentials of IWT on the Danube. They conclude that stakeholders from all involved countries report on similar types of barriers, thus standardization, harmonization, and digitization may remove or reduce many impacts of the revealed problems.

\section{DATA AND METHODS}

This paper focuses on priority area 1 of EUSDR, especially 1a (Waterways Mobility) to evaluate the achievement of targets, namely:

- Increase cargo transport on the river by $20 \%$ by 2020 compared to 2010 ;

- Solve obstacles to navigability, taking into account the specific characteristics of each section of the Danube and its navigable tributaries and establish effective waterway infrastructure management by 2020 . 
Data are from the period 2010 to 2017 , including some previous data on navigation. Bearing in mind that ongoing and recently completed projects will have effective results in the long term, primarily the related efforts are analysed.

Geographical scope of the study is the set of Danube riparian states. Taking into account the availability of data, national (country) level is analysed in all but one case: for Germany, data by the Bavarian statistical office is considered. Other data are from Eurostat and the European Commission's Statistical pocketbook 2018 (for EU member states), as well as the website of the Statistical Office for the Republic of Serbia (for non-member Serbia, indeed). Information about IWT projects has been gathered from the official website of EUSDR priority area 1a (www.danube-navigation.eu, last access on 31/3/2019).

A key aspect of this research is the evaluation of performances in the three Danube sections, thus groups of countries have been formed accordingly. Germany and Austria are countries of the Upper; Slovakia, Hungary, Croatia, and Serbia of the Middle; and Romania and Bulgaria of the Lower section (this last one includes the Danube-Black Sea Canal as well). Moldova and Ukraine are also Danube riparian states but, taking into consideration the lack of large scale investments in line with EUSDR, both countries are omitted in this study. (EU member states are in italics.)

In terms of developments, priority has been given to country-related projects, as these may be linked directly to states and subsequently river sections. Infrastructure investments are carried out mainly on a national level, thus commitment, motivation and efforts of single countries may also be evaluated by their analyses.

EUSDR coordinators initiated and labelled strategic projects, i.e. projects with high impact and visibility for the strategy in 2014 (see the list of strategic projects in Tab.1, in bold). These projects are analysed to the same extent as other initiatives in this paper.

Transport, neighbourhood and regional policy, as well as politics seem to be crucial for IWT development in this region, especially for sections where the Danube is a border river. There, bilateral cooperation is indispensable and some long held debates may hinder effective IWT developments. The border dispute between Croatia and Serbia or the dispute over the Gabčíkovo-Nagymaros dams between Slovakia and Hungary are the most relevant cases. However, politics and policy issues are ignored in the present study. 


\section{RESULTS}

Projects are analysed in three topics here: general aspects, navigability bottlenecks, and cargo transport on the Danube.

\section{General evaluation of IWT related projects in line with EUSDR}

Increasing cargo transport by $20 \%$, defined by environmental, sustainability and competitiveness considerations, seems to be a rather ambitious target, as it challenges the current trends of the transportation market, namely growing volumes and share of road transport. Modal share of IWT in all countries has been decreasing or remained unchanged from 2010 to 2015 (Fig. 1).

Figure 1 Modal share of IWT in Danube riparian EU member states

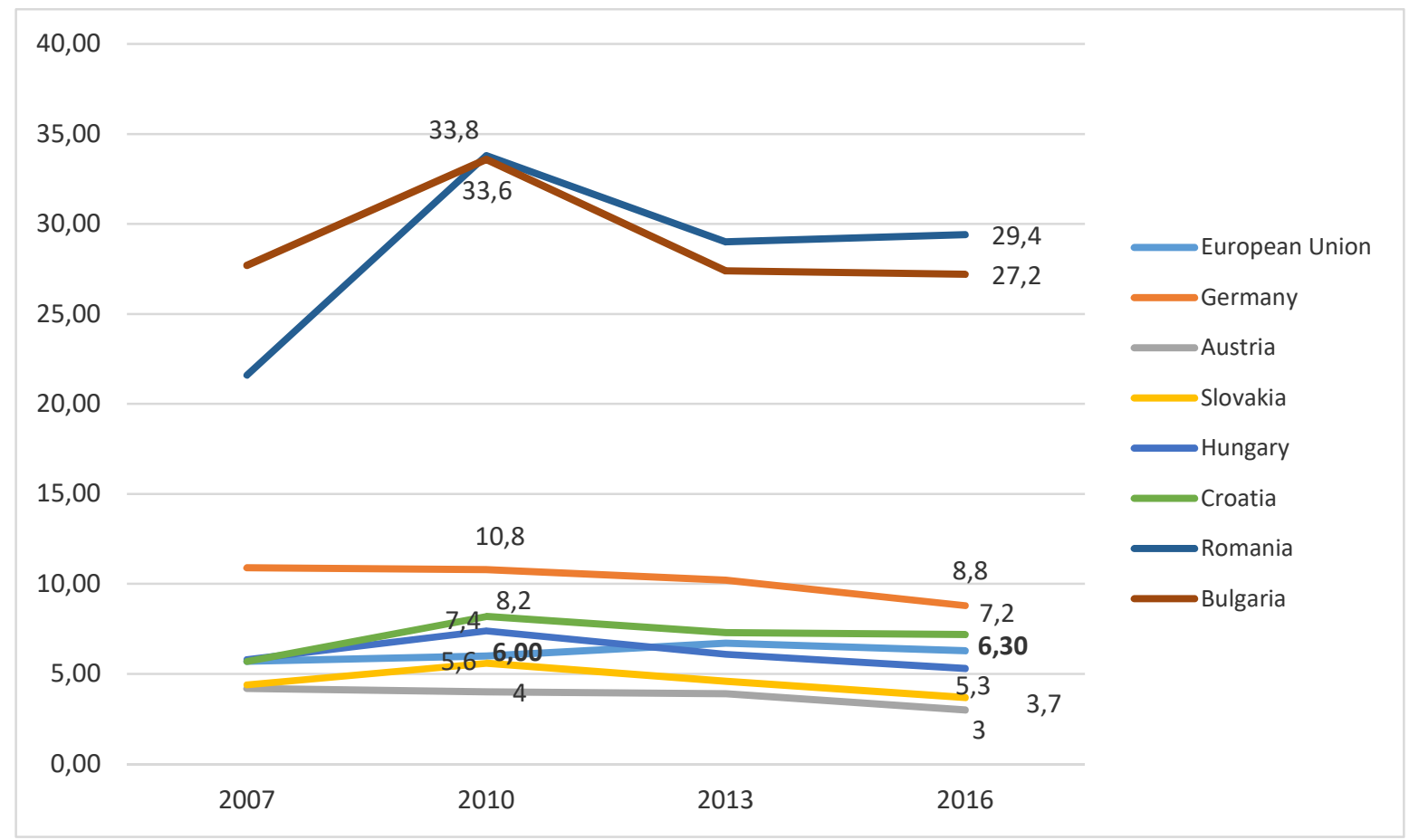

Source: own edition, data: Eurostat

Taking this into account, large scale and smart investments seem to be necessary to increase competitiveness of the IWT sector. Focusing on planned, ongoing and completed projects only by river sections, unbalanced distribution may be observed. (Project ideas are proposals in line with EUSDR, most of which did not succeed in earning co-financing in previous calls of EU programmes.) In 2019, approaching the end of the 7-year EU programming period (2014- 
2020), there are many completed projects, especially on a transnational level. Most projects are still ongoing in the Middle and Upper sections (Fig. 2). Some key investments in the latter are financed by national means and will still last for a long time (e.g. lock reconstructions in the Main-Danube Canal). In the Lower section, there are many more completed than ongoing projects.

Figure 2 Number of IWT projects in line with EUSDR, by river section

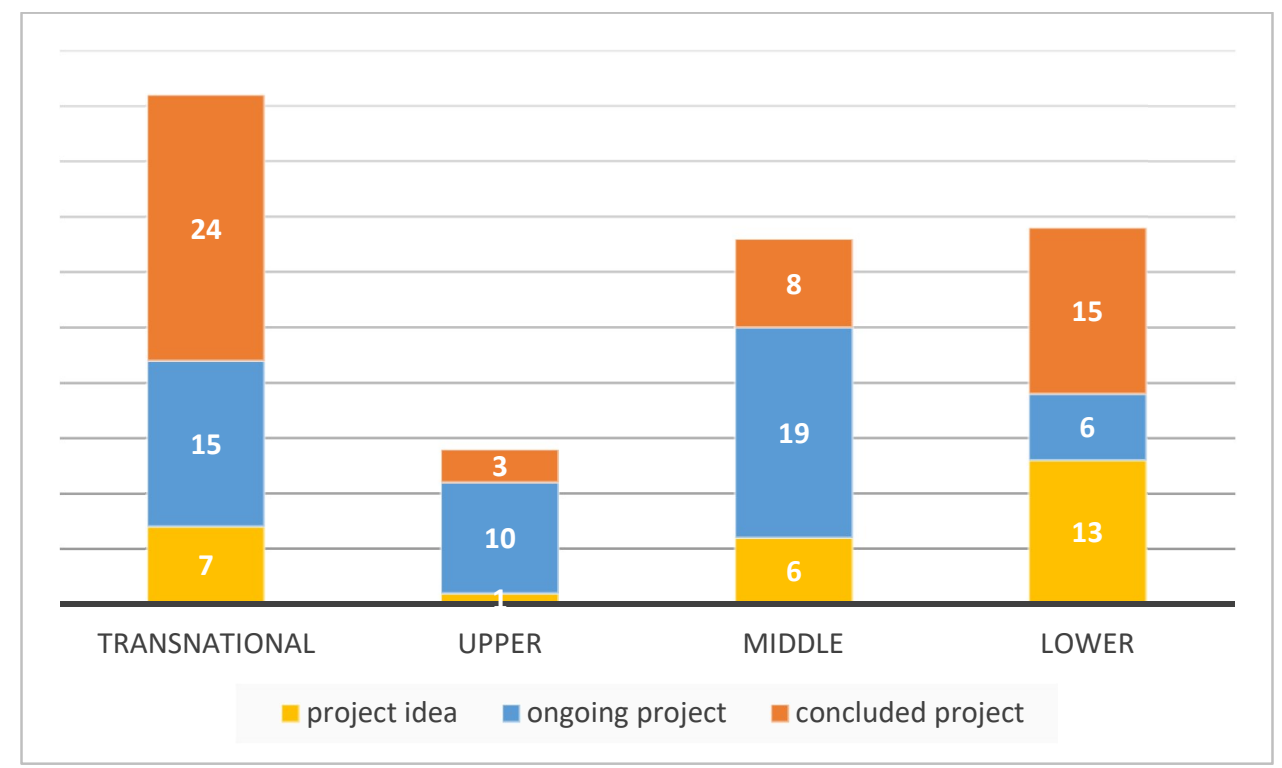

Source: own edition, data: danube-navigation.eu (last access: 31/3/2019)

The main purpose of transnational projects is to strengthen cooperation through borders among organisations of national and local character, NGOs and companies. In this set of projects, research and consultancy type projects are overrepresented. Although there are project leaders from most Danube riparian countries (Tab. 1), Austria has a dominant role, especially due to key organizations (via donau, Pro Danube International) and its efforts in integrating others. Projects led by Austrian companies are based on wide scale partnerships, including a good number of organisations from (in a good number of cases, nearly all) the riparian states. As the Danube is not the only large navigable waterway and only one part of the country is included in the EUSDR initiatives, Germany has fewer projects as project leader. On the contrary, Romania is more active than others, e.g. Hungary or Slovakia. Thus, on the level of river sections, the Upper and Lower sections seem to have more affinity for project leadership. 
Table 1 Transnational projects in line with EUSDR by the end of 2018

\begin{tabular}{|c|c|c|c|c|}
\hline Project name (or brief description in italic), EUSDR strategic projects in bold & Project & Term & $\begin{array}{l}\text { Budget } \\
\text { urrin }\end{array}$ & Status \\
\hline CO-WANDA (convention for waste management, follow-up of WANDA) & AT & $2012-2014$ & 1.82 & $\checkmark$ \\
\hline DaHar - Danube Inland Harbour Development & HU & $2011-2014$ & 1.97 & $\checkmark$ \\
\hline DANTE - Improving Administrative Procedures and Processes for Danube IWT & AT & $2017-2019$ & 1.98 & 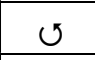 \\
\hline Danube SKILLS (increase institutional capacity by boosting competences) & RO & $2017-2020$ & 2.02 & $\circlearrowleft$ \\
\hline Danube Stream - Smart, Integrated And Harmonized Waterway Management & $\mathrm{AT}$ & $2017-2019$ & 2.11 & $u$ \\
\hline DAPhNE - Danube Ports Network & AT & $2017-2019$ & 2.99 & $\circlearrowleft$ \\
\hline DBS Gateway Region (transnational multi-port gateway region) & AT & $2017-2019$ & 2.18 & $\circlearrowleft$ \\
\hline Development of Transport and Navigation on the Sava River Waterway & HR & $2008-$ & 85 & $\circlearrowleft$ \\
\hline DREAM - Danube River Research And Management & AT & $2012-2020$ & 69.6 & $\circlearrowleft$ \\
\hline ECCONET - Effects of Climate Change on the Inland Waterway Networks & $\mathrm{BE}$ & $2010-2012$ & 2.26 & $\checkmark$ \\
\hline Energy Barge - Building A Green Energy And Logistics Belt & $\mathrm{DE}$ & $2017-2019$ & 2.32 & 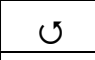 \\
\hline EWENT - Extreme Weather Impacts On European Networks Of Transport & FIN & $2009-2012$ & 1.92 & $\checkmark$ \\
\hline FAIRway Danube (deployment of a fairway maintenance master plan) & AT & $2015-2020$ & 23.4 & 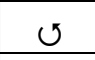 \\
\hline FAST DANUBE (technical assistance for a feasibility study) & RO & $2014-2018$ & 5.25 & $\checkmark$ \\
\hline Green Danube (integrated transnational policies and practical solutions) & RO & $2017-2019$ & 1.59 & $\circlearrowleft$ \\
\hline GRENDEL - Green and Efficient Danube Fleet & AT & $2018-2020$ & 1.83 & 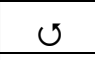 \\
\hline High-Performance Green Port Giurgiu & RO & $2013-2015$ & 0.66 & $\checkmark$ \\
\hline HINT (harmonized IWT through education and information technology) & $\mathrm{RO}$ & $2012-2014$ & 1.54 & $\checkmark$ \\
\hline Innovative Danube Vessel & AT & $2012-2013$ & 0.29 & $\checkmark$ \\
\hline INWAPO - Upgrading Of Inland Waterway And Sea Ports & IT & $2011-2014$ & 3.81 & $\checkmark$ \\
\hline IRIS Europe II - Implementation Of River Information Services In Europe & AT & $2009-2011$ & 11.63 & $\checkmark$ \\
\hline IRIS Europe 3 - Implementation of River Information Services in Europe & AT & $2012-2014$ & 10.46 & $\checkmark$ \\
\hline LNG Masterplan for Rhine-Main-Danube & AT & $2013-2015$ & 20.48 & $\checkmark$ \\
\hline Move It! - Modernisation Of Vessels For Inland Waterway Freight Transport & NL & $2011-2014$ & 3.96 & $\checkmark$ \\
\hline MreNa - Feasibility Study: Morava River - Recreational Navigation & SK & $2012-2014$ & 0.23 & $\checkmark$ \\
\hline NELI (cooperation network for logistics and nautical education) & RO & $2009-2012$ & 2.17 & $\checkmark$ \\
\hline NEWADA - Network Of Danube Waterway Administrations & AT & $2009-2012$ & 2.86 & $\checkmark$ \\
\hline NEWADA Duo (data and user orientation of the waterway administration network) & AT & $2012-2014$ & 2.24 & $\checkmark$ \\
\hline NEWS (next generation European inland waterway ship and logistics system) & AT & $2012-2015$ & 2.21 & $\checkmark$ \\
\hline PlasticFreeDanube - Macro Plastic Waste in and along the Danube & AT & $2017-2020$ & 1.5 & 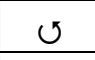 \\
\hline PLATINA - Platform for the Implementation of NAIADES & $\mathrm{AT}$ & $2008-2012$ & 8.79 & $\checkmark$ \\
\hline PLATINA II - Platform for the Implementation of NAIADES & AT & $2013-2016$ & 2 & $\checkmark$ \\
\hline PROMINENT - Promoting Innovation In The Inland Waterways Transport Sector & NL & $2015-2018$ & 6.58 & $\checkmark$ \\
\hline RIS COMEX - RIS Corridor Management Execution & AT & $2016-2020$ & 26.5 & $\circlearrowleft$ \\
\hline RISING (RIS services for improving the integration of IWT into intermodal chains) & DE & $2009-2012$ & 7.52 & $\checkmark$ \\
\hline SEE Mariner (system for monitoring the transportation of dangerous goods) & GR & $2011-2013$ & 2.19 & $\checkmark$ \\
\hline SuperGreen (supporting EU's Freight transport logistics action plan ...) & GRE & $2010-2013$ & 3.45 & $\checkmark$ \\
\hline SWIM - Smart Waterway Integrated Management & RO & $2016-2020$ & 12.22 & $\circlearrowleft$ \\
\hline WANDA - Waste Management For Inland Navigation On The Danube & AT & $2009-2012$ & 1.67 & $\checkmark$ \\
\hline
\end{tabular}

Source: own edition, data: danube-navigation.eu (last access: 31/3/2019) 
Taking into account national projects on a country level, Romania is the most active. Its activity is outstanding especially in light of the low number of projects in the other country of the Lower Section, Bulgaria. The Upper section is also unbalanced, as Germany carried or is carrying out more projects than neighbouring Austria. However, as it has already been stated, Austria is much more active in transnational cooperation. The number of developments is more balanced in the Middle section countries.

Differences seem to be less relevant in terms of project budget than in the number of projects. There are large scale investments on the Upper section with national financial resources and contributions by the market. Total budget of projects in general and of completed projects is the lowest in the Middle section. The highest amounts have been allocated to investments in the Lower section, and projects are still ongoing there in the amount of approximately 800 million EUR. On country level, amounts dedicated to IWT projects are high in Romania, Germany, and -due to the construction of an LNG terminal for 686.8 million EUR between 2017 and 2020-Slovakia. In Austria, the relatively low number of projects are realised by large budgets.

Figure 3 illustrates that, in spite of a balanced distribution of financial resources for IWT projects on the level of river sections, the picture is different on the level of countries of a certain section. It seems that countries like Bulgaria and Hungary, i.e. two member states that joined the EU well before the implementation of EUSDR (in 2004), did not make all the necessary efforts to find or did not succeed in achieving (co-)financing for IWT investments in line with the strategy. Croatia became an EU member state in 2013, thus it had a special situation in the early years of the macro-regional strategy. 
Figure 3 Budget of IWT projects in line with EUSDR by the end of 2018

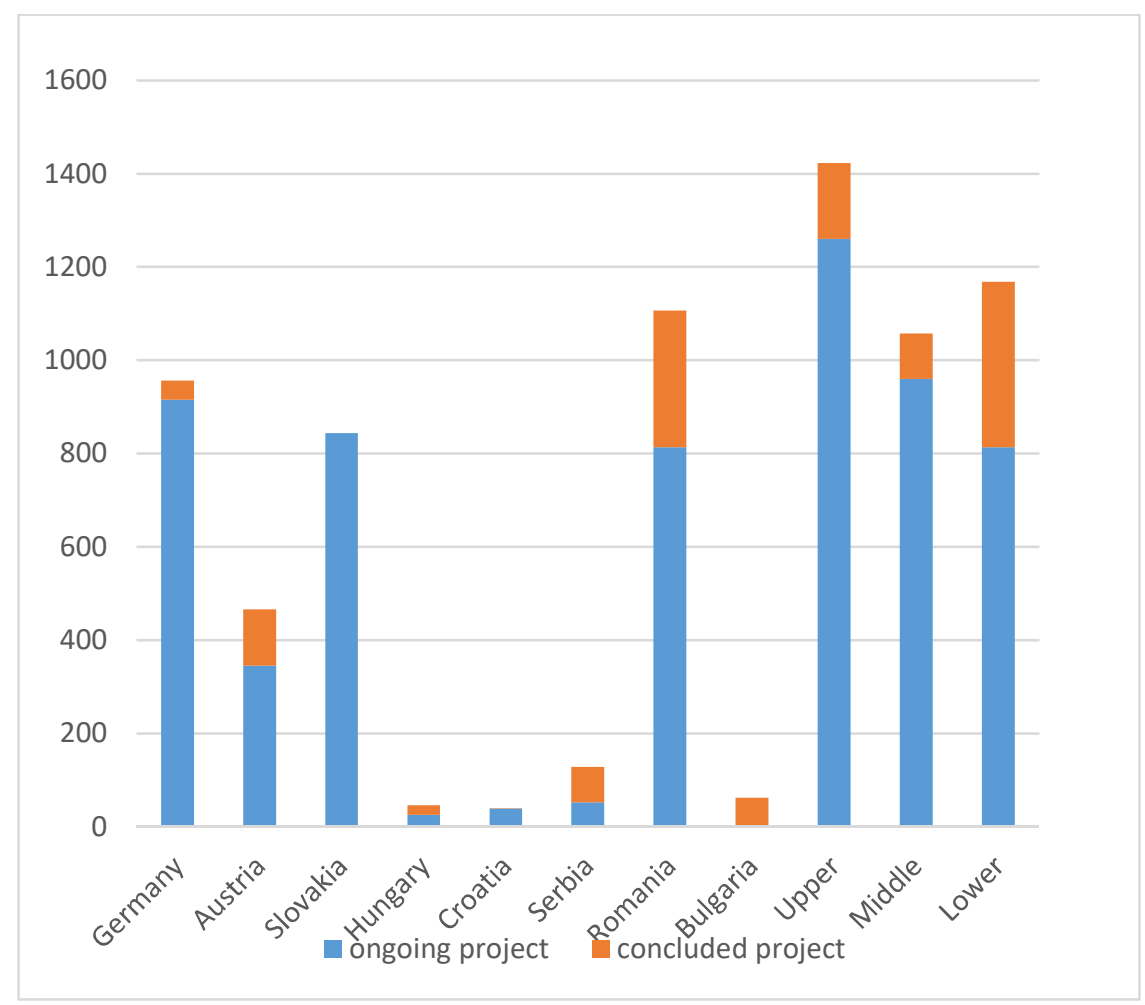

Source: own edition, data: danube-navigation.eu (last access: 31/3/2019)

Project goals of the dedicated budget have also been analysed (Fig. 4). The elaboration of studies and development of information systems logically have smaller budgets than waterway and port infrastructure projects. In the Middle section, more money is allocated to port development (especially due to the distortion effect by the above mentioned large scale LNG terminal project in Slovakia). In the Upper and Lower sections, the traditionally expensive waterway infrastructure investments earned large financial resources. In other words, the Middle section, where navigability problems are critical, minimal budgets have been spent for waterway development and maintenance. Furthermore, relatively low amounts of money are dedicated to research and preparatory studies on a national level in the Middle and Lower sections, which may hinter the implementation of large-scale projects in the near future there. It is questionable if the participation in international and transnational projects could replace the elaboration of specific national strategies, action plans, and other (e.g. research) documents. 
Figure 4 Budget of IWT projects in line with EUSDR by goal, per country and per section, by the end of 2018

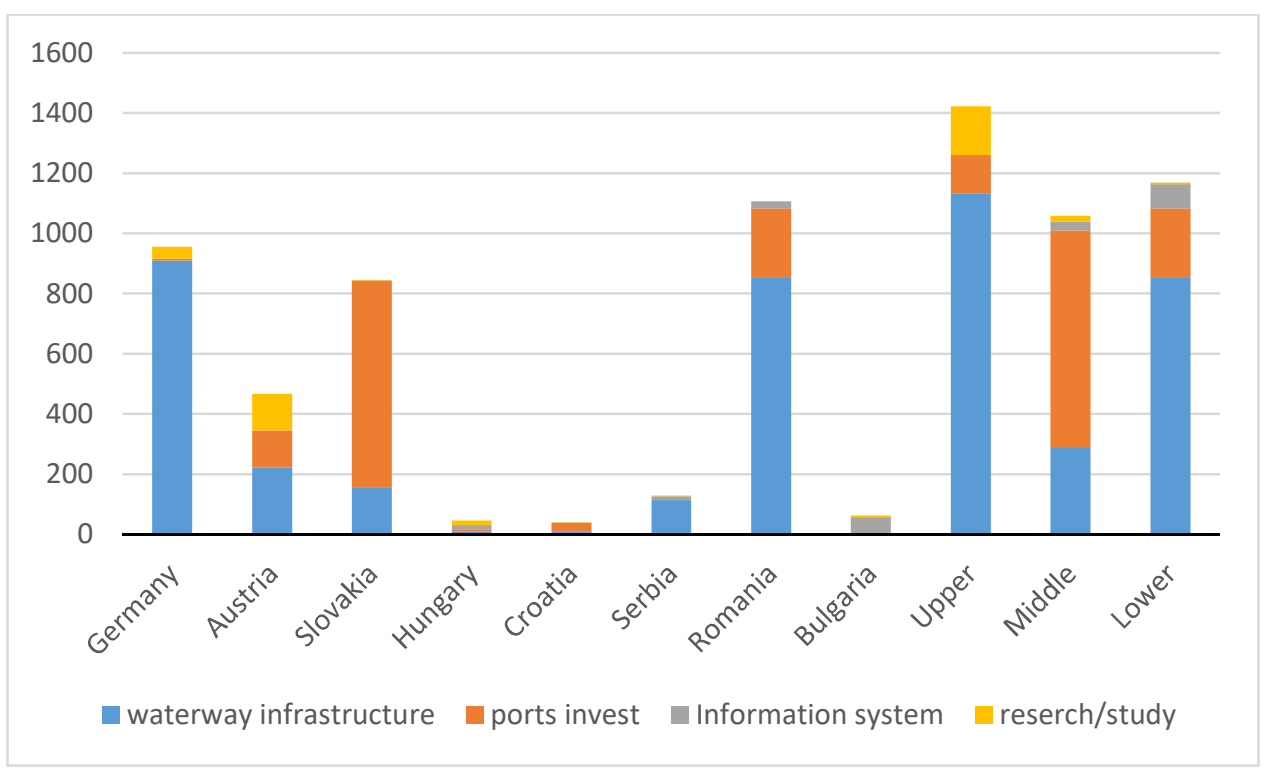

Source: own edition, data: danube-navigation.eu (last access: 31/3/2019)

On a country level, some further specalities may be observed. Bulgaria dedicates most of its modest budget to information system projects. Hungary and Croatia, both with a low number of projects in total, spend almost nothing for waterway development. In Slovakia and Romania, the proportion of research is quite low. Nevertheless, Austria spends nearly the same (relatively good) amount of money for waterway development, research, and port investments. Furthermore, its participation in international cooperation is also mainly related to "soft" projects.

Despite the inevitable role of research and preparatory studies and the development of information systems, navigability targets may be achieved primarily by investment projects. Countries allocate their budgets to physical interventions on different scales. As river section related common points have not been identified in this term, Fig. 5 shows four groups of countries, according to the amount of money dedicated to investments. 
Figure 5 Total budget of waterway infrastructure and port investment projects in line with EUSDR (in million EUR)

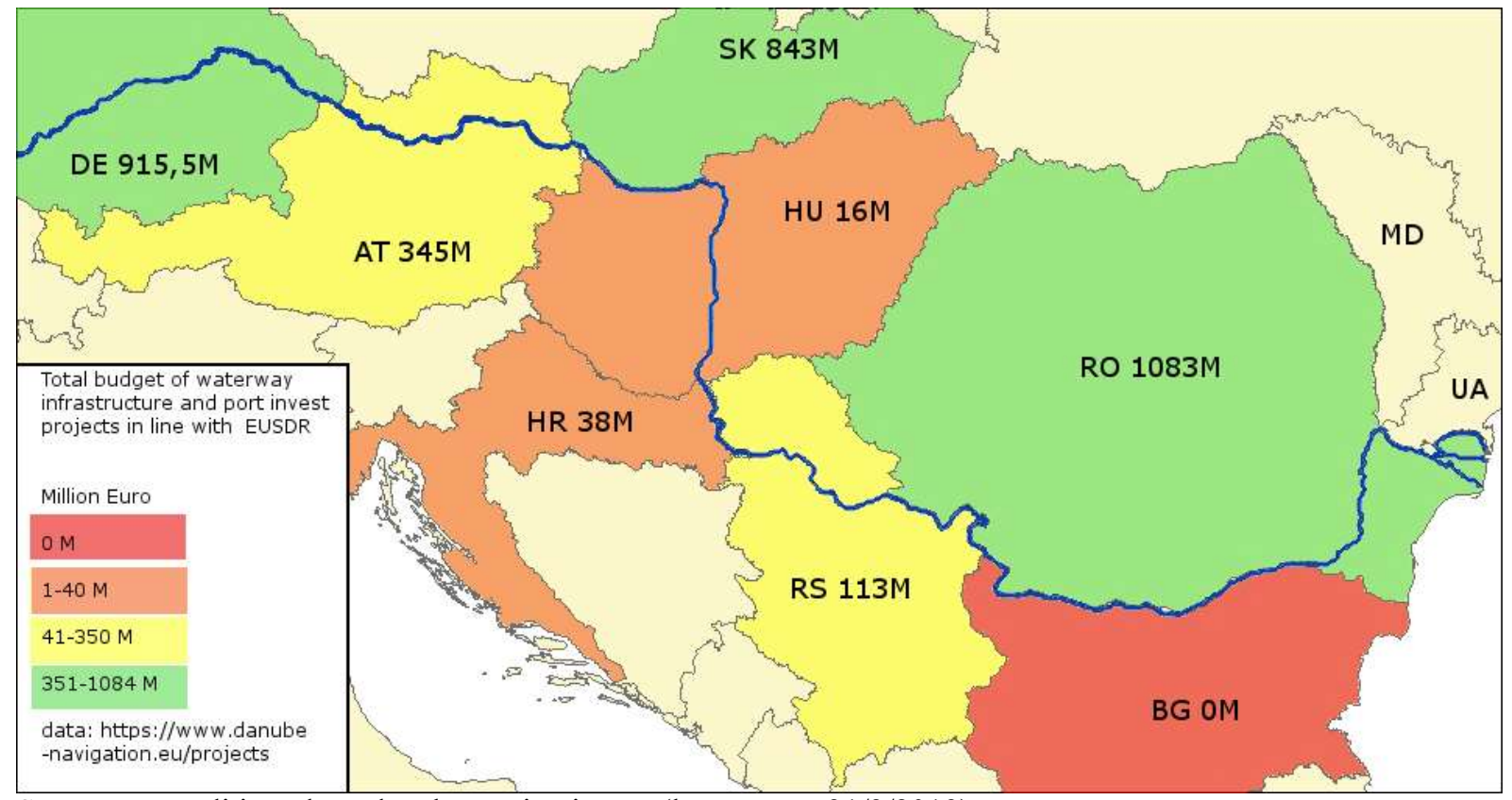

Source: own edition, data: danube-navigation.eu (last access: 31/3/2019)

In Germany, the reconstruction of locks helps further development of the Danube-Main Canal.

Multimodal port enhancement and large scale river engineering projects are being carried out in Austria. Construction of an LNG terminal in the public port of Bratislava makes Slovakia one of the largest port investors of the region in the frame of EUSDR. A comprehensive development programme is realised by Romania to improve its waterways and ports, giving priority to the Danube-Black Sea Canal and the port of Constanţa. In Serbia, the construction of a new bridge in place of the destroyed Žeželj Bridge in Novi Sad (completed in 2018) and upgrade of the Iron Gate I navigational lock are the projects with the largest budgets. In Hungary and Croatia, small scale interventions in waterway infrastructure and minor port developments are being done. According to this database (see Tab. 2), Bulgaria has not carried out waterway infrastructure or port investment projects. However, in 2014-2015, in line with the LNG Masterplan for Rhine-Main-Danube by the European Commission (2012), an LNG terminal with a capacity of $1000 \mathrm{~m}^{3}$ has been built in the Port of Ruse. 
Table 2 Waterway infrastructure and port invest projects in line with EUSDR by the end of 2018

\begin{tabular}{|c|c|c|c|c|c|}
\hline Project name (or brief description in italic) & Type & Country & Term & Budget & Status \\
\hline Overhaul of Kachlet & Waterway & $\mathrm{DE}$ & $2012-2019$ & 86 & $\circlearrowleft$ \\
\hline Reconstruction of the Erlangen Lock & Waterway & $\mathrm{DE}$ & $2015-2025$ & 203 & 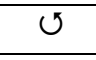 \\
\hline Reconstruction of the Kriegenbrunn Lock & Waterway & $\mathrm{DE}$ & $2015-2024$ & 210 & $\checkmark$ \\
\hline Reconstruction of the Obernau Lock & Waterway & $\mathrm{DE}$ & $2015-2030$ & 120 & 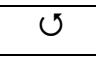 \\
\hline Upgrade Of The Danube Between Straubing And Vilshofen & Waterway & $\mathrm{DE}$ & $2015-$ & 208 & $\circlearrowleft$ \\
\hline Deepening of the Fairway of the Lower Main & Waterway & $\mathrm{DE}$ & $2015-$ & 28 & $\circlearrowleft$ \\
\hline Deepening of the Fairway of the Upper Main & Waterway & $\mathrm{DE}$ & $2000-2020$ & 55 & 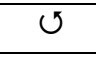 \\
\hline Core Network Port Regensburg - Improving Accessibility & Port & $\mathrm{DE}$ & $2016-2018$ & 5.48 & $\circlearrowleft$ \\
\hline Trimodal Linz Port - Rail Connection and Port Enhancement & Port & AT & $2017-2023$ & 122.9 & $\checkmark$ \\
\hline Integrated River Engineering Project & Waterway & $\mathrm{AT}$ & $2005-2030$ & 222 & $\circlearrowleft$ \\
\hline Construction of the LNG Terminal in the Public Port of Bratislava & Port & SK & $2017-2020$ & 686.8 & $\circlearrowleft$ \\
\hline DaReM - Danube Rehabilitation Measures & Waterway & SK & $2017-2020$ & 9.75 & $\checkmark$ \\
\hline Upgrade of Gabčíkovo Locks & Waterway & SK & $2016-2020$ & 146.6 & $\circlearrowleft$ \\
\hline PAN-LNG-4-DANUBE & Port & $\mathrm{HU}$ & $2016-2019$ & 7.01 & $\circlearrowleft$ \\
\hline HUMARK (improving fairway marking system in Hungary) & Waterway & $\mathrm{HU}$ & $2015-2020$ & 8.92 & $\circlearrowleft$ \\
\hline Slavonski Brod Port Infrastructure Construction and Upgrade & Port & HR & $2017-2020$ & 11.68 & $\circlearrowleft$ \\
\hline Construction of Bulk Cargo Terminal in the Port of Osijek & Port & HR & $2017-2021$ & 17.31 & $\circlearrowleft$ \\
\hline International Ship Winter Shelter on the Danube in Croatia & Waterway & HR & $2011-2020$ & 4,1 & $\mathcal{U}$ \\
\hline Rehabilitation of the Right Bank of the Danube River at km 1,322 & Waterway & HR & $2011-2020$ & 4,8 & $\circlearrowleft$ \\
\hline Rehabilitation of the Critical Sectors on the Sava River & Waterway & $\mathrm{RS}$ & $2017-2020$ & 7 & $\circlearrowleft$ \\
\hline Rehabilitation and Upgrade of the Iron Gate I Navigational Lock & Waterway & RS & $2017-2020$ & 28.51 & $\circlearrowleft$ \\
\hline River training and dredging works on critical sectors of the Danube & Waterway & RS & $2017-2020$ & 14.1 & $\circlearrowleft$ \\
\hline Construction of New Žeželj Bridge in Novi Sad & Waterway & RS & 2011-2018 & 60 & $\checkmark$ \\
\hline Removal of unexploded ordnance (UXO) from the Danube river & Waterway & RS & $2010-2012$ & 3.48 & $\checkmark$ \\
\hline PROTECT (upgrade of infrastructure in Constanța Port) & Port & RO & $2016-2019$ & 12.7 & 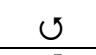 \\
\hline Rehabilitation of locks on the Danube-Black Sea Canal & Waterway & RO & $2013-2019$ & 348.3 & $\circlearrowleft$ \\
\hline High Performance Green Port Giurgiu Stage II - Construction & Port & RO & $2015-2019$ & 15.59 & $\circlearrowleft$ \\
\hline Banks Consolidation in the Poarta Alba-Midia Navodari Canal & Waterway & RO & $2014-2025$ & 309.2 & 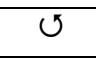 \\
\hline Improving navigation conditions on the Danube (rkm 375-175) & Waterway & RO & $2011-$ & 47.84 & $\checkmark$ \\
\hline Banks Protection on the Sulina Canal & Waterway & RO & $2004-$ & 80 & $\circlearrowleft$ \\
\hline Rehabilitation and development of the Oltenița Port infrastructure & Port & $\mathrm{RO}$ & $2012-2016$ & 4.81 & $\checkmark$ \\
\hline Completion of the North Breakwater in the Constanța Port & Port & RO & $2011-2015$ & 175 & 7 \\
\hline Road bridge at km 0+540 of the Danube-Black Sea Canal & Waterway & RO & $2010-2016$ & 49.43 & $\checkmark$ \\
\hline Development of the railways capacity in the port of Constanța & Port & $\mathrm{RO}$ & $2012-2015$ & 17.5 & $\checkmark$ \\
\hline Ship-generated waste collection and processing system & Waterway & RO & $2012-2015$ & 9.54 & $\checkmark$ \\
\hline CODENAV (ship waste management in the maritime Danube ports) & Waterway & $\mathrm{RO}$ & $2010-2013$ & 10 & 7 \\
\hline Dismantling/remaking of pushed convoys & Port & RO & $2012-2014$ & 3.5 & 7 \\
\hline
\end{tabular}

Source: own edition, data: danube-navigation.eu (last access: 31/3/2019)

\section{Navigability bottlenecks}

Solving obstacles to ensure navigability all year round is difficult due to the constantly changing formation of the riverbed. In addition to large engineering projects, maintenance of river facilities, riverbed monitoring, and dredging are all necessary. Although works may also form 
a barrier to navigation, floods, iceing, and low water levels are the main obstacles. Low water is the most challenging, as it may last for a long time and it cannot be solved by quick technical interventions.

Draughts below 2.5 meters cause reduced freight capacity for larger vessels. On some critical river sections, this is a recurrent bottleneck (Figure 6). Fairway conditions and progress of developments are monitored by FAIRway Danube (EUSDR strategic project, 2015-2020) several times per year. The report of October 2018 underlines that Croatia, Romania, and Bulgaria have satisfied more than half of the national investment needs declared in 2014 (bmvit and via donau 2018b). The report for the complete year of 2017 has identified 20 main critical sections where the recommended draught of 2.5 metres at low navigable water level was not achieved. Water levels started to decrease in June in both the Middle and Lower sections, and this led to unfavourable fairway conditions during the entire summer period. Besides weather conditions, this is due to insufficient waterway maintenance or interventions. The most critical location was Cochirleni in Romania, where the minimum depth was not achieved from July to October in 2017. Although the same data for 2018 was not available by the finalisation of this manuscript, it is well-known that fairway conditions were less favourable in 2018 compared to previous years, which led to temporary closures of navigation on all sections of the Danube.

Figure 6 Critical fairway locations 2017

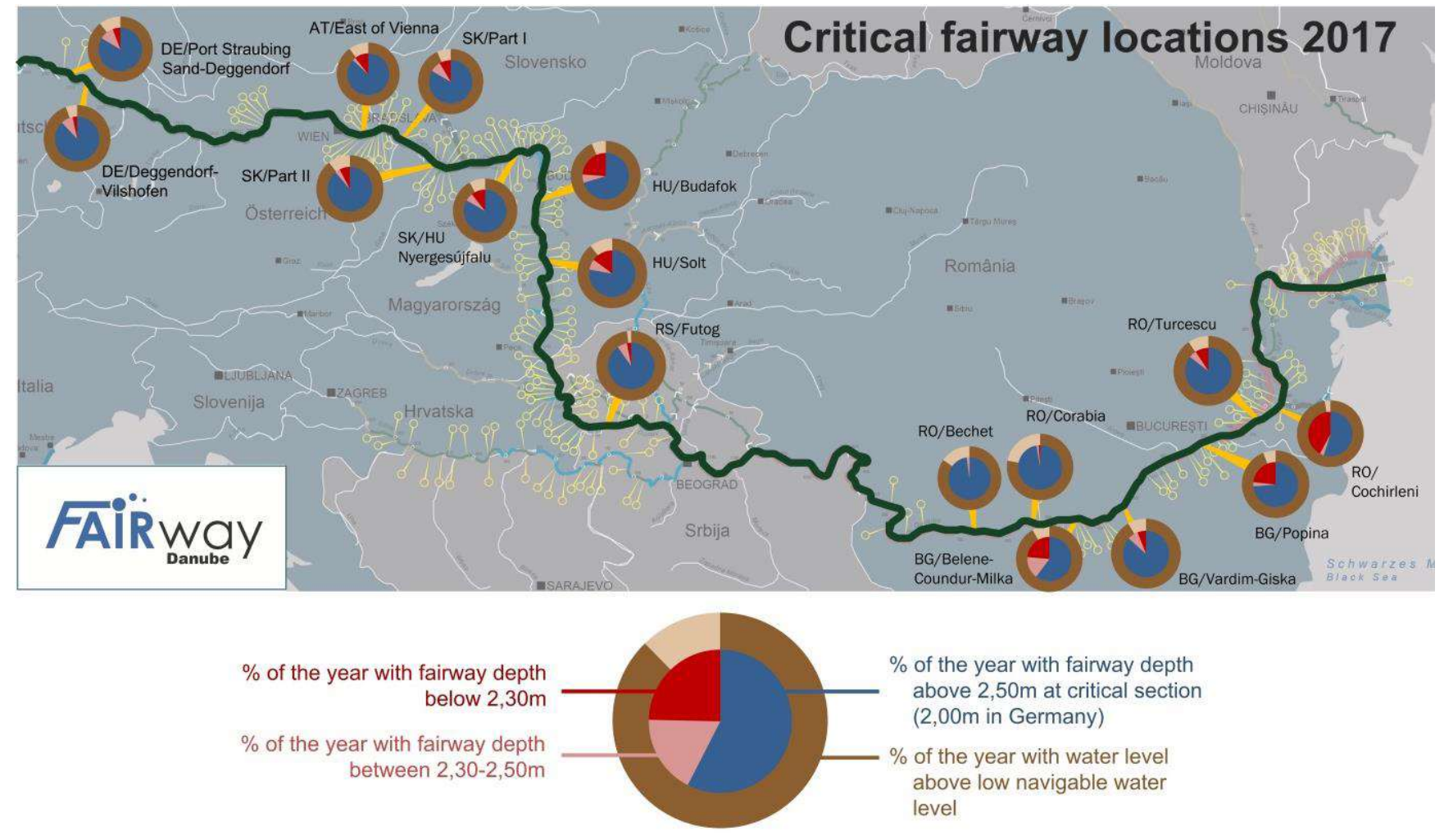

Source: bmvit \& via donau (2018a), p. 18 
The quality of waterway infrastructure is crucial for the IWT sector. The Austrian waterway company (via donau) carried out a survey in December 2017 to evaluate maintenance activities upon feedbacks by ship captains, ship owners, and others in the industry (in total, 114 respondents). Outcomes show the need for improvement explicitly. On the Upper section, more than 70\% (in Austria, more than 90\%) of respondents evaluated maintenance activities as excellent or good. In the Middle section, this is near $50 \%$, and in the Lower section, only approximately $25 \%$ (via donau 2018).

Figure 7 Water infrastructure quality in the Danube countries in 2017

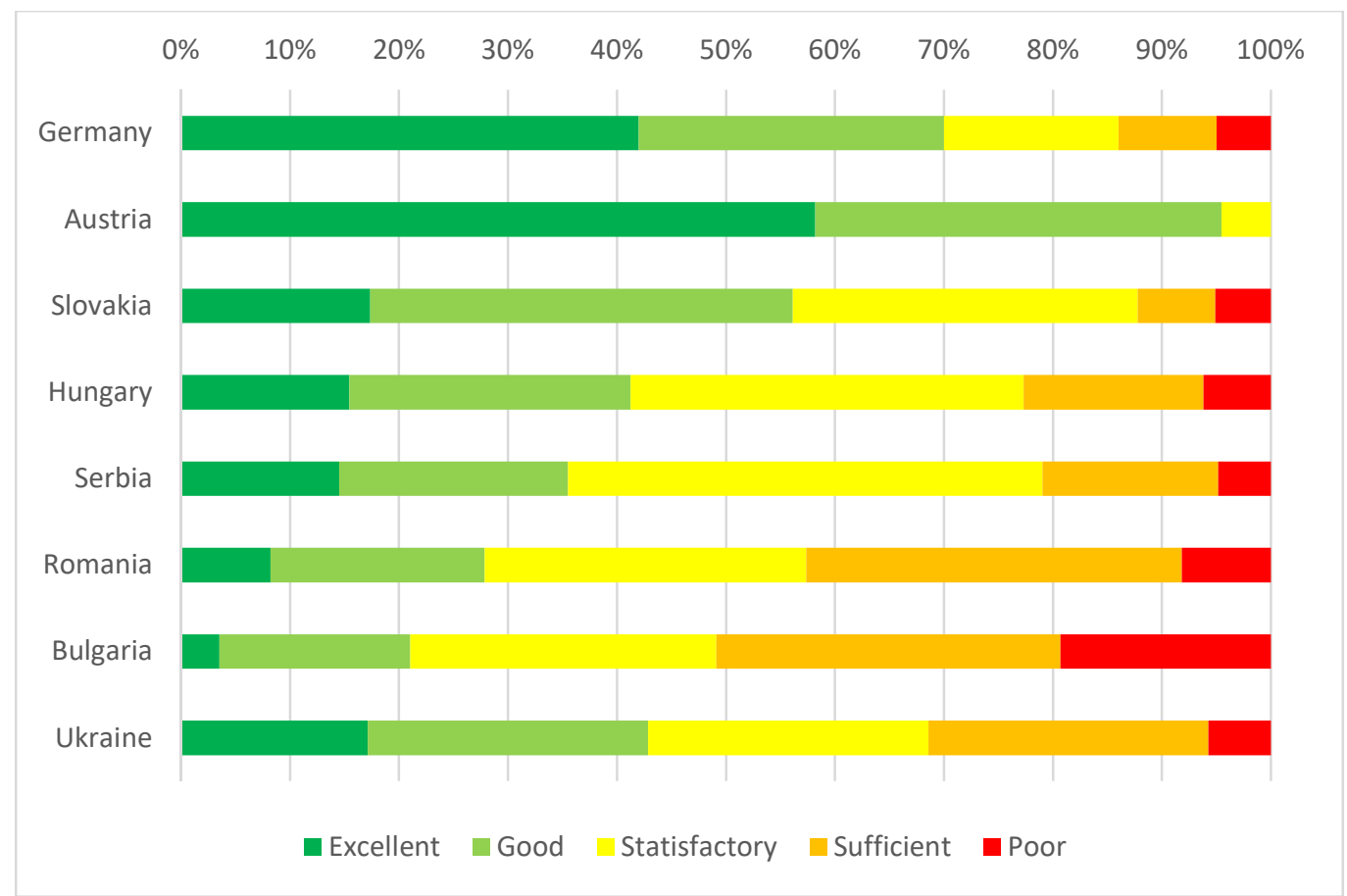

Source: own edition, data: via donau

\section{Volume of cargo transport on the Danube}

As stated above, freight transport on the Danube was relevant in the 1980s. By that time, some key infrastructure investmens had been done and a large fleet of vessels was in operation on the fairway. The Danube played a key role in the foreign trade of socialist countries, where economic and political frameworks allowed the provision of industrial towns along the Danube with cheap raw materials from the Black Sea.

The dissolution of the Soviet Union and subsequent economic recession in Eastern Europe, as well as new political trends and wars largely affected the IWT sector. New transportation needs to and from Western Europe, and the development of the related Trans-European rail and road networks led to the reduction of the market of inland navigation and put it into a worsening 
position. The current status of IWT is the result of a decline after the global financial and European debt crisis. Transport volumes hit bottom in 2011 and thereafter they are stagnating (Fig. 8); by 2017, none of the Danube riparian states could exceed freight transport volumes of 2010. The largest traffic is in Romania and freight transport volumes are significant in Bulgaria as well. The latter is true -in spite of rather poor IWT infrastructure quality (see Fig. 7)- thanks to the relative proximity of the Black Sea, relevance of domestic and transit transport, as well as shortcomings of land transport infrastructures and connections. In Austria, Slovakia, Hungary, and Croatia, 5 to 10 thousand tonnes are forwarded yearly, and there have been no relevant changes in the analysed years. The lowest volumes are transported on the Danube in Germany and Serbia.

Figure 8 Goods transport by inland waterways per country in 2010-2017

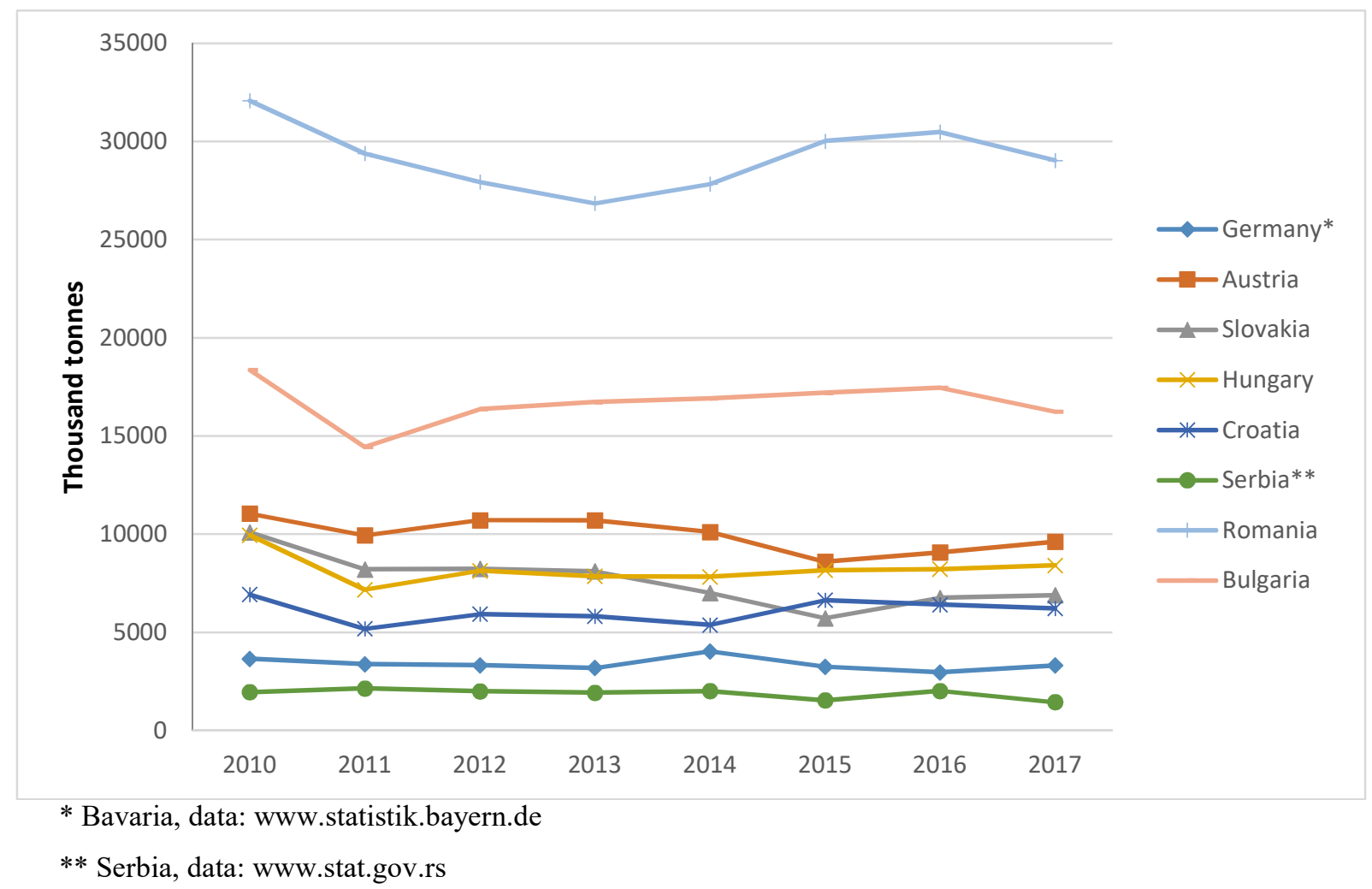

Source: own edition, data: Eurostat, BSV, stat.gov.rs

On the level of river sections (Figure 9), the Lower region is dominant, due to direct link to the sea, the operation of sea and sea-river ports and needs for domestic freight transport on the Danube. On the Middle section, export, import, and transit are relevant. Austrian raw material needs are prevalent in the Upper region. 
Figure 9 Freight transport per Danube section (in thousand tonnes) in 2010-2017

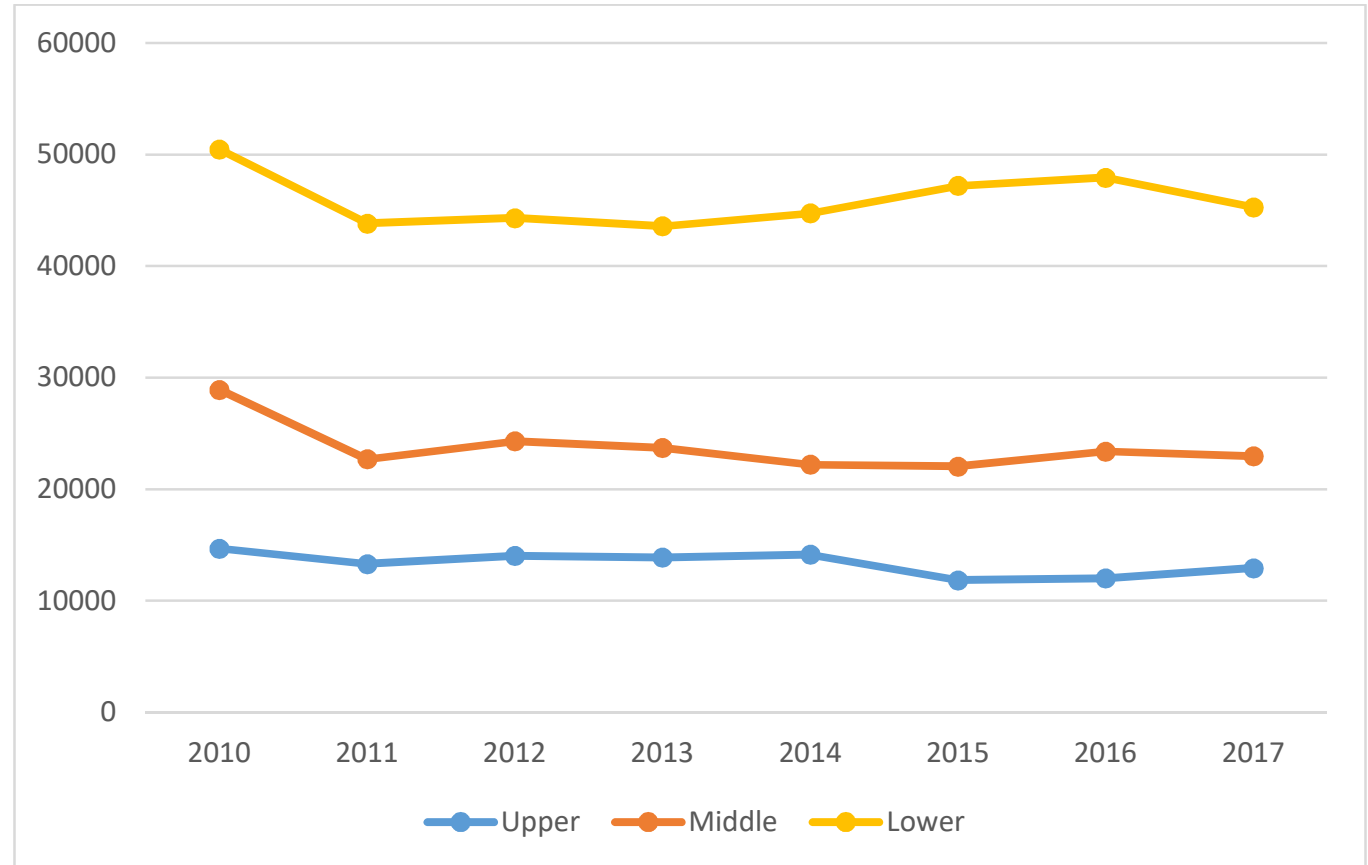

Source: own edition, data: Eurostat, BSV, stat.gov.rs

More than half of the freight transport on the Danube (in tonnes transported) are attached to the Lower section. Transport volumes show particular proportions in this comparison (Fig. 9): the Lower section compares to the total volumes like the Middle section to the Lower; performances of the Upper section are nearly the same - approximately half - in relation to the Middle section.

Figure 10 Distribution of freight transport per Danube section (in tonnes) in 2017 
Freight transport on the Danube may be divided into export, import, transit, and domestic traffic. Import and transit prevail in the Upper section and transit and export in the Middle. The Lower section is the only one where domestic traffic is significant; in contrast, logically, transit is low. Serbia seems to be atypical, maybe partly in line with its position in the border of two sections; although export and transit were responsible for the largest volumes in 2016, import and domestic traffic were also relevant there. In this respect, distribution of volumes in both Serbia and Bulgaria are balanced. Low proportion of transit in Romania is due to its position and outstanding volumes of IWT in general.

Figure 11 Distribution of freight transport on the Danube by the type of traffic in 2016

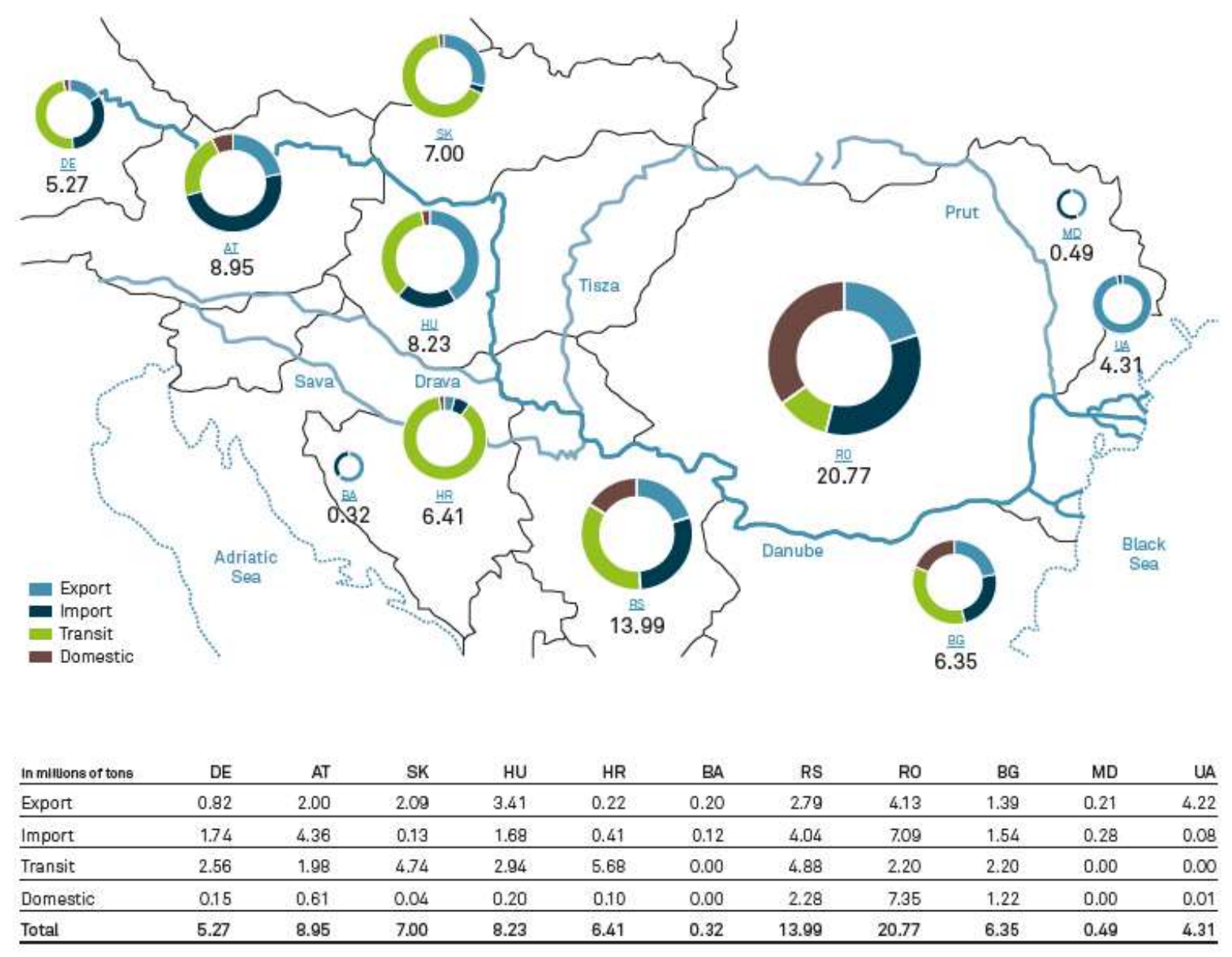

Source: via donau 2018, p. 40

Transport volumes are illustrated by Figure 12. Comparison of the data of 2010 and 2017 (in thousand tonnes) is visualized on the map. As there is decline in all countries, changes have been grouped into four categories. Belonging to a certain river section seems to be characteristic, e.g. downturn is salient in the Middle section, especially in Slovakia and Serbia. Although taking into account weather (and subsequent fairway) conditions of the analysed years 
would be logical here, this is ignored especially for the impartial evaluation of EUSDR targets. The Strategy addresses improvements of navigability in general, i.e. it targets waterway infrastructure and maintenance levels that allow or even promote the transport of the targeted volumes in almost all conditions. And although this is a late mid-term evaluation, some positive achievements would be necessary by now in order to reach the targets for 2020. By the way, similar trend (decline) would be seen if the data were in tonne-kilometers, as well (European Union 2018).

Figure 12 Change of freight transport volumes on the Danube (2017/2010, in tonnes)

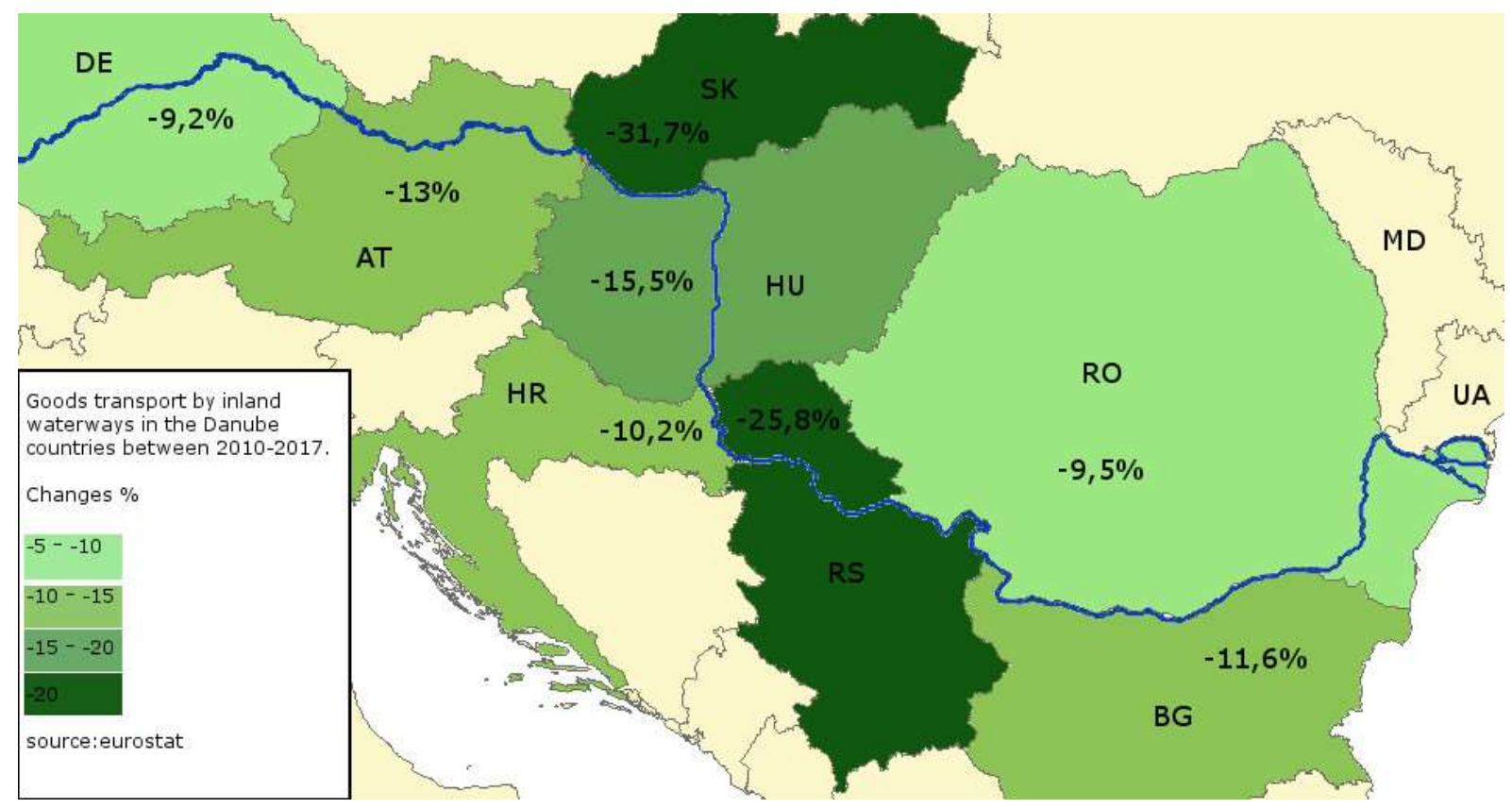

Source: own edition, data: eurostat

\section{DISCUSSION AND CONCLUSION}

In this paper, impacts of EUSDR in the IWT sector have been reviewed. One of the key findings is that social, political, and economic differences previously revealed by the literature are relevant for this topic, as well: the three (Upper, Middle, and Lower) river sections have different characteristics in terms of inland navigation efforts, opportunities, and performances. Freight transport data, types of transport (export, import, transit, domestic), and the range of developments all justify this categorization. Indeed, there are some exceptions, such as the case of Slovakia, where a large scale port development project makes its investment budget similar to the Upper section countries. From the same point of view, Bulgaria would belong to the Middle section countries (except Slovakia), due to its moderated activity to carry out developments. 
Nagy, D., Munkácsy, A., Jászberényi, M.

With regard to the research questions (related to EUSDR targets) raised in the introduction, it may be underlined that the expected increase of transport volumes on the Danube from 2010 to 2017 (or expectedly by 2020) is not being achieved. Moreover, freight transport volumes (in tonnes) declined from 2010 to 2017. It seems that, in spite of the future outcomes of many ongoing projects in line with EUSDR, revolutionary changes are needed to effectively promote inland navigation in the macro-region. Not only well-defined infrastructure developments are necessary, but also programmes to improve multimodality and IWT competitiveness, taking into account the future of the entire transport system and other single sectors, especially road and rail (Jászberényi \& Munkácsy 2018). Better cooperation within EUSDR (e.g. among projects or between priority areas $1 \mathrm{a}$ and $1 \mathrm{~b}$ ), as well as with other strategies and programmes would also be useful.

The study of developments in line with EUSDR pointed out, among other findings, that commitment of countries may be completely different. Although navigability in the Middle section is a key issue for increasing competitiveness, only very limited resources have been dedicated to waterway improvements and port investments there (except for Slovakia for some extent in terms of ports), where low water levels may be critical. On the contrary, Romania seems to be a promoter and a main beneficiary of IWT developments. Austria has a key role in initiating and leading transnational projects, as well as coordinating research activities.

Data availability is an evident limitation of this study. By early 2019, a year before the expected targets of EUSDR in terms of inland navigation, 2017 data was available for the analysis. The complete period of 2010 to 2020 may (and shall) be evaluated in 2022 or even later. Meanwhile there is a lot to do, not only by EUSDR priority area coordinators, member state institutions and other potential project partners, but also scholars. As stated above, EUSDR and IWT are both under-researched topics, thus researchers shall devote further efforts to properly study inland navigation and interpret the impacts of EUSDR, as well as translate their findings into policy recommendations and practical solutions.

\section{REFERENCES}

Beuthe, M., Jourquin, B., Urbain, N., Lingemann, I. \& Ubbels, B. (2014). Climate change impacts on transport on the Rhine and Danube: A multimodal approach, Transportation Research Part D: Transp ort and Environment, 27, 6-11

Beyer, A. (2018). Inland waterways, transport corridors and urban waterfronts, International Transport Forum Discussion Papers, OECD Publishing, Paris.

bmvit \& via donau (2018a). Fairway Rehabilitation and Maintenance Master Plan for the Danube and its navigable tributaries: National Action Plan. Update May p. 162 
bmvit \& via donau (2018b). Fairway Rehabilitation and Maintenance Master Plan for the Danube and its navigable tributaries: National Action Plan. Update October p. 130

Chilla, T. \& Sielker, F. (2016). Measuring the added-value of the EUSDR-challenges and opportunities. Input Paper for DG Regio and Danube Strategy Point, Brussels.

Czakó, K., Fekete, D. \& Poreisz, V. (2014). Economic Differences of Countries by the River Danube, Procedia Economics and Finance, 9(1-2), 163-175.

Gál, Z., Lux, G., \& Illés, I. (2013). (Eds.), Danube Region: Analysis and Long-Term Development Trends of the Macro-Region, Pécs, Magyarország: Institute of Regional Studies, Centre for Economic and Regional Studies, Hungarian Academy of Sciences, 59 p.

European Commission (2010), European Union Strategy for Danube Region, Communication From the Commission to the European Parliament, the Council, the European Economic and Social Committee and the Committee of the Regions

European Commission (2012). LNG Masterplan for Rhine-Main-Danube Masterplan for introduction LNG as fuel and as cargo for inland navigation 2012-EU-18067-S, Bruxelles.

European Union (2018). EU Transport in Figures. Statistical Pocketbook 2018. Publications Office of the European Union, Luxembourg

Glock, K., Tritthart, M., Gmeiner, P., Pessenlehner, S. \& Habersack, H., (2019). Evaluation of engineering measures on the Danube based on numerical analysis, Journal of Applied Water Engineering and Research, 7(1), 48-66

Hardi, T. (2012). Duna-stratégia és területi fejlödés, Akadémiai Kiadó

Habersack, H., Heinbc, T., Stanicad, A., Liska, I., Mair, R., Jäger, E., ...Bradley C. (2016). Challenges of river basin management: Current status of, and prospects for, the River Danube from a river engineering perspective, Science of The Total Environment, Volume 543, Part A, Pages 828-845

Ignjatijević, S., Milojević, I., Cvijanović, G., \& Jandrić, M. (2015). Balance of Comparative Advantages in the Processed Food Sector of the Danube Countries. Sustainability, 7(6), 6976-6993.

Jászberényi, M., \& Munkácsy, A. (2018). (Eds.): Közlekedés, mobilitás, turizmus. Akadémiai Kiadó, Budapest

Mihic, S., Golusin, M., \& Mihajlovic, M., (2011). Policy and promotion of sustainable inland waterway transport in Europe - Danube River, Renewable and Sustainable Energy Reviews, Volume 15, Issue 4, Pages 1801-1809

Müller, B. \& Hannes, L. (2015). Socio-economic assessment of the Danube Region: State of the region, challenges and strategy development. Future strategic orientation of the EUSDR. ZEW-Gutachten und Forschungsberichte, Mannheim

Ngampramuan, S. (2018). Evaluating the EUSDR's contribution to sub-regional integration processes. Australian \& New Zealand Journal of European Studies 10.2

Pfoser, S., Jung, E., \& Putz, L. (2018). Same river same rules? - Administrative barriers in the Danube countries. Journal of Sustainable Development of Transport And Logistics, 3(3), 27-37.

Radmilović Z., \& Maraš V. (2011). Role of Danube inland navigation in Europe. International Journal for Traffic and Transport Engineering, 1(1), 28-40.

Rafaelsen, B., Wähler C. L., Weitzel-Mudersbach, M., Sanopoulos, A., Grozea-Helmenstein, D. \& Paterson, I. (2017). Study on macro-regional strategies and their links with cohesion policy. Data and analytical report for the EUSDR, COWI

Sielker, F. (2016). New approaches in European governance? Perspectives of stakeholders in the Danube macro-region. Regional Studies, Regional Science 3(1), 88-95.

Ţarţavulea, R. I., Belu, M. G. \& Paraschiv, D. M. (2011). The EU Strategy of Development for Inland Water Transport on the Danube. Intermodality and Logistics Services Ovidius University Annals, Economic Sciences Series, XI. (1), 2185-2190.

via donau (2018). Annual Report on Danube Navigation in Austria. via donau, Vienna, 46 p. 